Prepared for the U.S. Department of Energy

under Contract DE-AC05-76RL01830

\title{
Sage-Grouse and Wind Energy: Biology, Habits, and Potential Effects from Development
}

JM Becker

JD Tagestad

CA Duberstein

JL Downs

July 2009

Pacific Northwest

NATIONAL LABORATORY

Proudly Operated by Battelle Since 1965 


\section{DISCLAIMER}

This report was prepared as an account of work sponsored by an agency of the United States Government. Neither the United States Government nor any agency thereof, nor Battelle Memorial Institute, nor any of their employees, makes any warranty, express or implied, or assumes any legal liability or responsibility for the accuracy, completeness, or usefulness of any information, apparatus, product, or process disclosed, or represents that its use would not infringe privately owned rights. Reference herein to any specific commercial product, process, or service by trade name, trademark, manufacturer, or otherwise does not necessarily constitute or imply its endorsement, recommendation, or favoring by the United States Government or any agency thereof, or Battelle Memorial Institute. The views and opinions of authors expressed herein do not necessarily state or reflect those of the United States Government or any agency thereof.

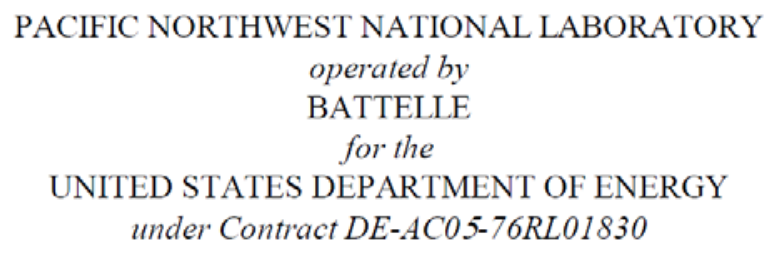

Printed in the United States of America

$$
\begin{aligned}
& \text { Available to DOE and DOE contractors from the } \\
& \text { Office of Scientific and Technical Information, } \\
& \text { P.O. Box 62, Oak Ridge, TN } 37831-0062 \text {; } \\
& \text { ph: (865) 576-8401 } \\
& \text { fax: (865) 576-5728 } \\
& \text { email: reports@adonis.osti.gov }
\end{aligned}
$$
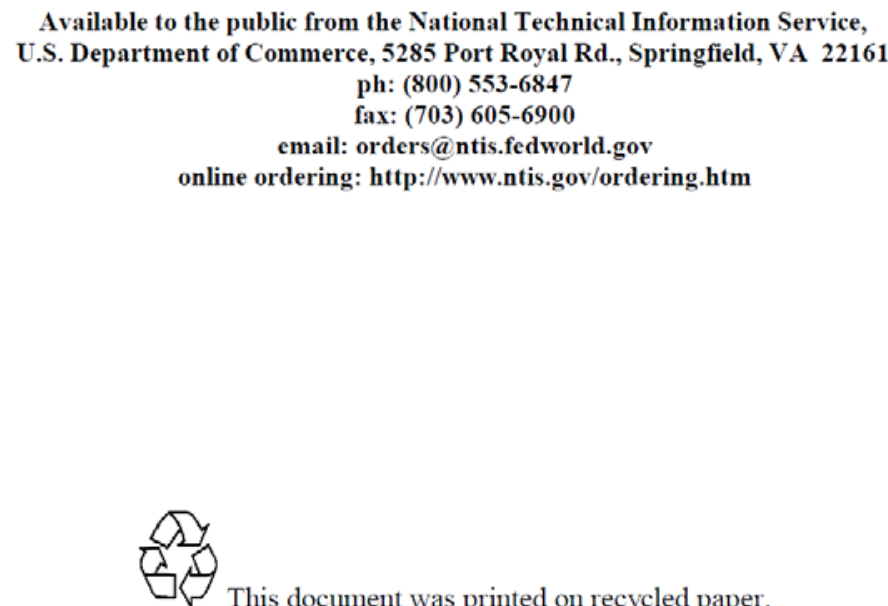

This document was printed on recycled paper. 


\title{
Sage-Grouse and Wind Energy: Biology, Habits, and Potential Effects of Development
}

\author{
JM Becker CA Duberstein \\ JD Tagestad JL Downs
}

July 2009

Prepared for

the U.S. Department of Energy

Office of Energy Efficiency and Renewable Energy

Wind \& Hydropower Technologies Program

under Contract DE-AC05-76RL01830

Pacific Northwest National Laboratory

Richland, Washington 99352 


\section{Summary}

Proposed development of domestic energy resources, including wind energy, is expected to impact the sagebrush steppe ecosystem in the western United States. The greater sage-grouse relies on habitats within this ecosystem for survival, yet very little is known about how wind energy development may affect sage-grouse. The purpose of this report is to inform organizations of the impacts wind energy development could have on greater sage-grouse populations and identify information needed to fill gaps in knowledge.

Sage-grouse are highly dependent on sagebrush-dominated landscapes for all phases of their life history. Much of their current range overlaps with wind power resources characterized as superb to good across 11 western states. Sage grouse may utilize different habitats during different seasons and usually require a large home range. However, they are habitual, using specific locales during all seasons, and are sensitive to habitat disturbance. Sage-grouse populations have generally been in decline since the mid1960s; the species is currently under review for listing as threatened or endangered by the U.S. Fish and Wildlife Service.

Very little is known about wind energy and sage-grouse, but oil- and gas-field developments within the range of the sage-grouse often have caused measureable effects to their populations. Activities and disturbance related to both energy development scenarios are believed to pose some similar threats to the grouse. Sage-grouse populations typically decline following oil and gas development, and birds have been displaced from habitat near infrastructure and locations with human. Notably, it has been shown that female grouse nesting in developed areas had lower annual survival rates. Chick mortality rates also were higher within sight of oil wells.

It is not known to what extent the development of wind energy resources will affect sage-grouse populations. Information on local and landscape-level impacts is needed. Before-after control-impact studies are needed to determine impacts to grouse, and information gained could be used within an adaptive management strategy. Research protocols and efforts should be developed collaboratively between industry, resource management, and the research community. 


\section{Acknowledgments}

Funding for the compilation and production of this primer was provided by the Wind \& Hydropower Technologies Program within the Office of Energy Efficiency and Renewable Energy, U.S. Department of Energy. Jack Connelly, principal wildlife research biologist with the Idaho Cooperative Fish \& Wildlife Research Unit, Idaho State University, and Karin Sinclair, senior project leader for the National Wind Technology Center, National Renewable Energy Laboratory, provided comments on an initial draft of the primer. Because of their insightful comments, this final version is much more effective at achieving its purpose. 


\section{Acronyms and Abbreviations}

$\begin{array}{ll}\text { BACI } & \text { before-after control-impact } \\ \text { BLM } & \text { U.S. Bureau of Land Management } \\ \text { BMP } & \text { best management practices } \\ \text { CBNG } & \text { coal-bed natural gas } \\ \text { DOE } & \text { U.S. Department of Energy } \\ \text { DOI } & \text { U.S. Department of the Interior } \\ \text { DPS } & \text { distinct population segment } \\ \text { FLPMA } & \text { Federal Land Policy and Management Act of 1976 } \\ \text { FSH } & \text { Forest Service Handbook } \\ \text { FSM } & \text { Forest Service Manual } \\ \text { IM } & \text { Instruction Memorandum } \\ \text { NEPA } & \text { National Environmental Policy Act of } 1969 \\ \text { NFMA } & \text { National Forest Management Act of } 1976 \\ \text { PEIS } & \text { programmatic environmental impact statement } \\ \text { POD } & \text { plan of development } \\ \text { ROD } & \text { Record of Decision } \\ \text { ROW } & \text { right-of-way } \\ \text { USFS } & \text { U.S. Forest Service } \\ \text { USFWS } & \text { U.S. Fish and Wildlife Service } \\ & \end{array}$




\section{Contents}

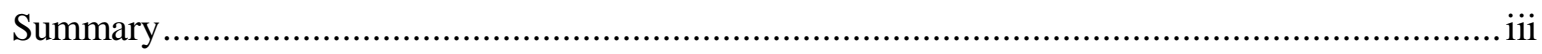

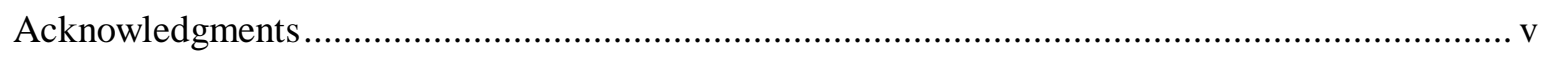

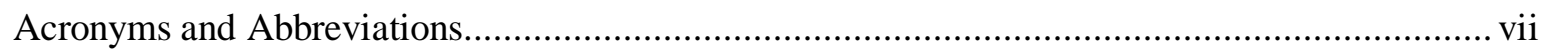

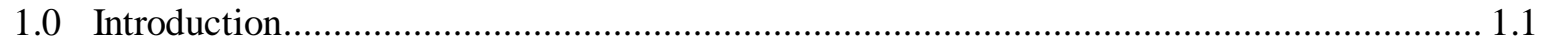

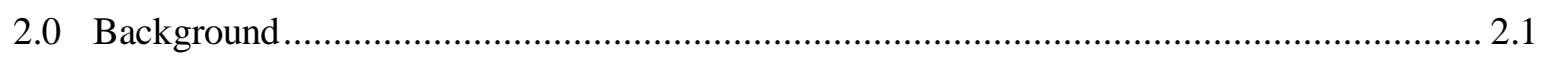

2.1 Sage-Grouse and Sagebrush Habitats ................................................................. 2.1

2.2 Energy Development in Sage-Grouse Habitats...................................................... 2.3

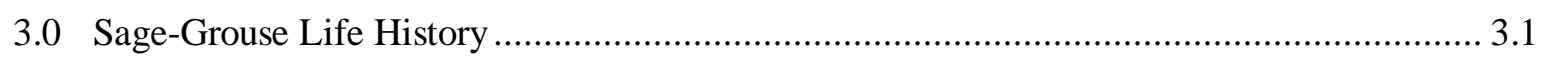

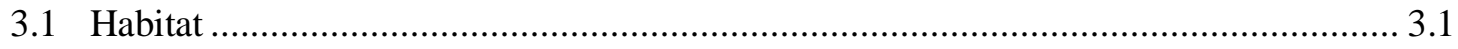

3.1.1 Breeding and Brood-rearing Habitat......................................................... 3.1

3.1.2 Autumn and Winter Habitat ................................................................. 3.1

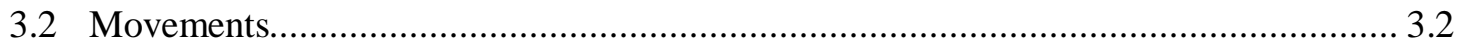

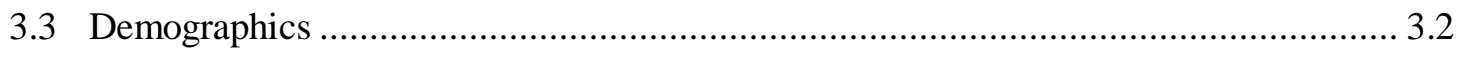

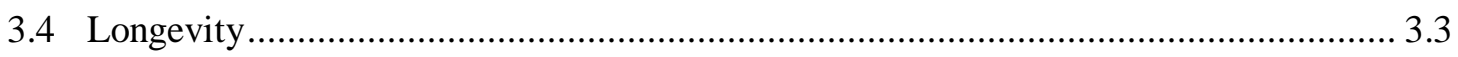

3.5 Distribution, Abundance, and Population Trends ....................................................... 3.3

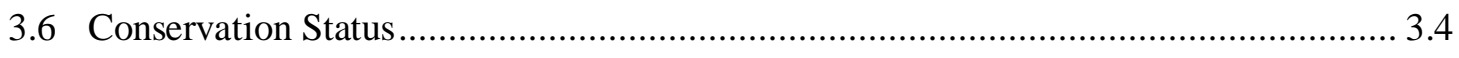

4.0 Impacts Related to Energy Development .................................................................. 4.1

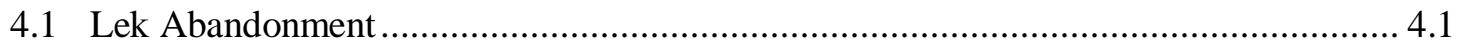

4.2 Nesting Area Fidelity and Reproductive Success .................................................. 4.3

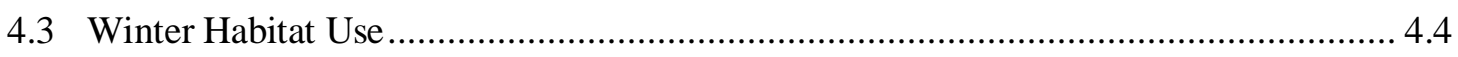

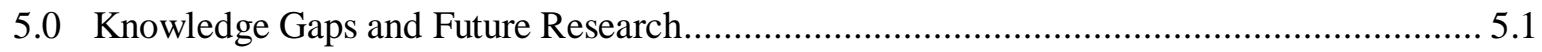

5.1 Research Needs and Priorities............................................................................ 5.1

5.2 Application of Research to Federal and State Land-Use Authorizations ...................... 5.2

5.3 Application of Research to Mapping Sage-Grouse Habitat Attributes.......................... 5.2

6.0 Literature Cited ................................................................................................. 6.1

Appendix A - Application of Research to Federal and State Land-Use Authorizations............... A.1 


\section{Figures}

2.1 Historical and Current Range of Greater (Centrocercus urophasianus) and Gunnison

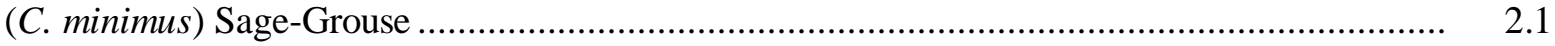

2.2 Overlay of Current Sage-Grouse Distribution with State Wind Energy Resources ................... 2.2 


\subsection{Introduction}

Current initiatives for developing domestic energy resources to fill U.S. energy demands have led to new development pressures on natural resources throughout the sagebrush steppe ecosystem (C. A. Hagen, personal communication). ${ }^{1}$ One of the most recent energy initiatives concerns wind energy development, which is projected to provide $20 \%$ of the U.S. energy by 2030 (DOE 2008). Wind resource areas in the western United States include large portions of the sagebrush (Artemisia spp.) steppe ecosystem (Connelly et al. 2004), much of which is inhabited by sage-grouse (Centrocercus urophasianus)-a species being considered for listing under the Endangered Species Act of 1973. Development of wind energy resources across the western United States holds the potential to impact sage-grouse across its current distribution (11 western states), and both land and wildlife managers and resource developers need information on how to avoid or minimize potential impacts to this species of concern. Little information is available to determine the potential effects of wind farms and wind energy development on sage-grouse populations, but recent investigations have attempted to assess the effects of other types of energy development (primarily oil and gas). Results of these studies may provide indications of potential impacts of wind energy on sage-grouse in the western United States.

The purpose of this report is to envisage how wind energy development could impact greater sagegrouse populations in the western United States through a review of available data and literature, identification of information gaps, and discussion of the research needed to address important data gaps regarding wind energy development and sage-grouse. This primer has three main objectives:

- to provide a brief background on sage-grouse biology and distribution

- to present a synthesis of issues that should be considered by resource developers and agencies currently involved in the siting, testing, permitting, and construction of wind energy projects

- to inform those organizations positioned to direct and facilitate research on the potential effects of wind energy development on sage-grouse.

Information on the current status of sage-grouse in the western United States and the potential impacts of development on this species will aid in constructing appropriate siting and permitting guidelines for wind energy facilities and identify related conservation measures for sage-grouse.

In this report, Section 2 introduces the reader to the sage-grouse and describes the potential for interaction between sage-grouse and wind energy interests. Section 3 provides more specific life-history information for the sage-grouse. Section 4 details the potential impacts of wind energy development on this species. Section 5 summarizes knowledge gaps and suggests areas where more research is needed to understand potential impacts. Literature cited is listed in Section 6. An Appendix provides suggestions for applying results of future research to federal and state decision making with respect to land-use authorizations for wind energy development.

\footnotetext{
${ }^{1}$ Hagen CA. 2009. Letter to the National Wind Coordinating Committee, Grassland Shrub-Steppe Species Collaborative, from Christian A. Hagen (Oregon Department of Fish and Wildlife), "Background and Rationale for Research Needs to Evaluate Impacts of Wind Energy Development on Greater Sage-Grouse Populations," January 8, 2009.
} 


\subsection{Background}

\subsection{Sage-Grouse and Sagebrush Habitats}

The largest grouse in North America, sage-grouse is named for its year-round dependence on sagebrush for both food and cover (Lyon 2000; Connelly et al. 2004; Aldridge et al. 2008; Doherty et al. 2008). For these reasons, it is considered a sagebrush-obligate species, and its distribution coincides with the distribution of sagebrush across the western United States (Schroeder et al. 1999; Connelly et al. 2004). The sage-grouse is a landscape specialist that requires large and intact sagebrush habitats to maintain populations (Connelly et al. 2004; Doherty et al. 2008). To date, the indirect effects of sagebrush habitat loss, fragmentation, and degradation, as well as direct effects of anthropogenic disturbance causing habitat avoidance and mortality, have resulted in the extirpation of sage-grouse from approximately 50\% of its original range (Figure 1) (Connelly and Braun 1997; Connelly et al. 2004; Schroeder et al. 2004; Kaiser 2006; Doherty et al. 2008; Naugle et al., in press).

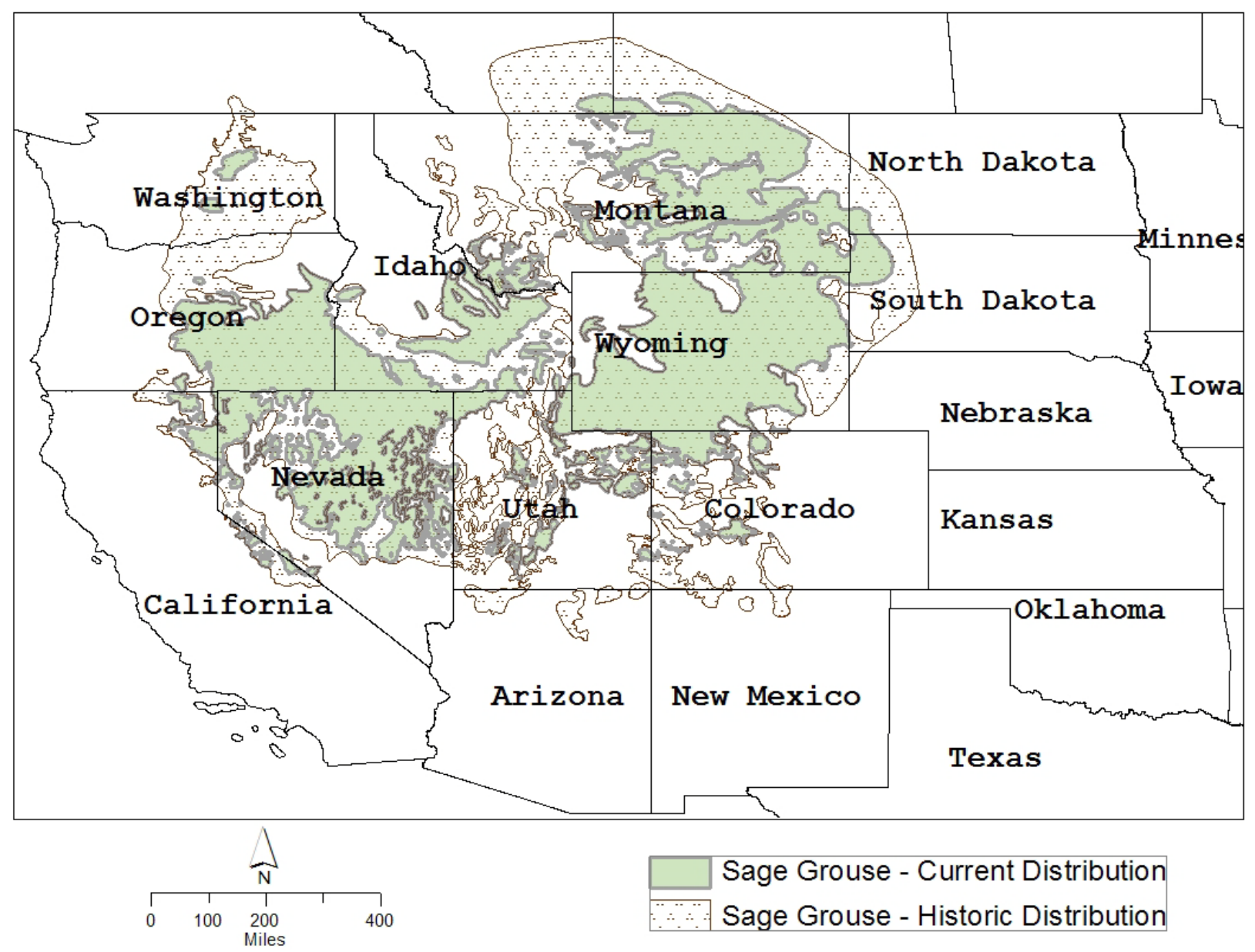

Figure 2.1. Historical and Current Range of Greater (Centrocercus urophasianus) and Gunnison (C. minimus) Sage-Grouse. Adapted from Schroeder et al. (2004). 
Wind farms are being established throughout the United States, including in sagebrush habitats. Current development of oil and gas resources also is occurring in sagebrush habitats that are occupied by sage-grouse. Almost $70 \%$ of the existing sagebrush steppe is publicly owned or managed by a state or federal agency. The U.S. Bureau of Land Management (BLM) has stewardship for about $50 \%$ of the sagebrush habitats in the United States and thus is the primary agency responsible for management of public lands containing sagebrush (Connelly et al. 2004; DOI 2005; Naugle et al., in press).

An overlay of current sage-grouse distribution with state wind energy resources (Figure 2) indicates that the potential development of wind energy resources overlaps the distribution of sage-grouse habitat virtually range-wide. Within the area of overlap are lands that may be suitable for wind energy development. Thus, like oil and gas energy development, wind energy development also will overlap populations of sage-grouse and available sage-grouse habitats.

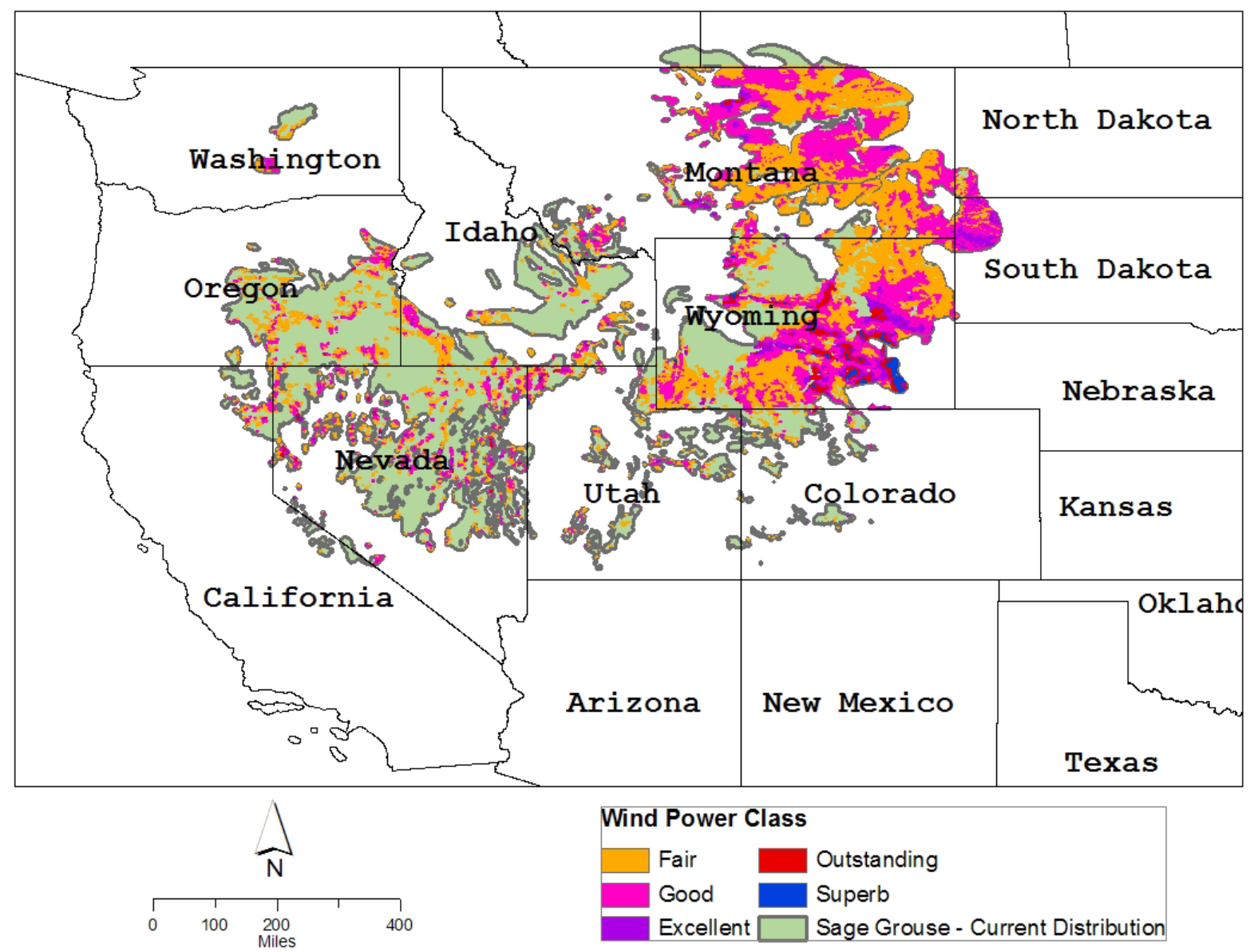

Figure 2.2. Overlay of Current Sage-Grouse Distribution with State Wind Energy Resources

The long-term viability of sage-grouse range-wide continues to be at risk because of population declines (Connelly et al. 2004; Connelly and Braun 1997), which are likely due to habitat loss and degradation as well as other disturbance that causes low recruitment rates (Connelly et al. 2007). Sagegrouse populations declined overall from 1965 to 2007, with the greatest declines occurring before the mid-1980s. Since then, populations continued to decline slowly but rebounded slightly after 2000 
(Connelly et al. 2004; Connelly and Braun 1997). The total range-wide population decline to date is estimated at $45 \%$ to $80 \%$ with local declines of $17 \%$ to $92 \%$ (Doherty et al. 2008).

The entire population of sage-grouse in the United States is currently under review for listing as threatened or endangered by the U.S. Fish and Wildlife Service (USFWS) (73 FR 10218). Impacts continue locally and cumulatively at the landscape scale. Because the sage-grouse requires large and intact sagebrush habitats, site-specific and local mitigation of impacts may be insufficient to sustain populations (Naugle et al., in press). In the last decade, research (e.g., on the effects of oil and gas resource development) and management and conservation (e.g., sage-grouse working groups coordinated between the states) have incorporated a landscape-level emphasis on habitat management.

\subsection{Energy Development in Sage-Grouse Habitats}

Information on the effects of wind energy on sage-grouse is largely lacking, although studies have been conducted to evaluate other types of energy development with activities and infrastructure similar to wind development (Lyon 2000; Lyon and Anderson 2003; Aldridge 2005; Holloran 2005; Kaiser 2006; Aldridge and Boyce 2007; Walker et al. 2007; Doherty et al. 2008). The decline in sage-grouse habitat and populations has been recognized over the past several decades, and a number of questions have arisen within the last 10 years concerning effects of energy development (including oil and natural gas development and exploration activities) on sage-grouse. Most of the literature and information reviewed for this primer is from the same period.

A panel of experts ranked infrastructure related to energy development and urbanization as the second most important extinction risk factor for sage-grouse after invasive species (70 FR 2244; Delach 2006). Infrastructure related to energy development, particularly that for oil and gas, has been shown to substantially affect habitat use by sage-grouse because of behavioral habitat avoidance and widespread habitat loss, degradation, and fragmentation. Because of its pace and spatial extent, oil and gas resource development is regarded as playing a major role in the decline of the species in the eastern portion of the species' range (70 FR 2244; Holloran 2005; Walker et al. 2007; Doherty et al. 2008; Naugle et al., in press). Augmentation of affected sage-grouse populations, via introduction of translocated birds or supplementation of existing populations, is often unsuccessful (Naugle et al., in press). Thus, continued development of oil and gas resources in the sagebrush ecosystem could continue to impact the sagegrouse population.

Wind energy development could likewise become a major issue for sage-grouse population management. The associated infrastructure and human activities, as well as effects unique to wind, may pose some threats to the species, similar to those that result from oil and gas development. The development of wind energy in conjunction with oil and gas (as well as other types of development) may pose cumulative synergistic direct and indirect effects on sage-grouse that are worthy of consideration.

Because large-scale development of wind energy resources is recent and ongoing, many of the potential impacts of wind energy development on sage-grouse have not been studied. However, potential development impacts to grouse population can be anticipated from studies of oil and gas development effects on the species. Identifying important information gaps regarding effects of wind energy development on sage-grouse, as well as the research needs and priorities that will fill these gaps, is a critical component of long-term strategies to enable both resource development and species protection. 


\subsection{Sage-Grouse Life History}

\subsection{Habitat}

Sage-grouse depend on a variety of shrub-steppe habitats throughout their life cycle. They are particularly tied to several species of sagebrush upon which they depend for much of their annual food and cover (68 FR 6500; Schroeder et al. 1999; Connelly et al. 2004). These species include big sagebrush (A. tridentata), silver sagebrush (A. cana), and threetip sagebrush (A. tripartita) during all seasons of the year; and low sagebrush (A. arbuscula) and black sagebrush (A. nova) during spring and winter. However, other shrub species such as rabbitbrush (Chrysothamnus spp.), antelope bitterbrush (Purshia tridentata), and horsebrush (Tetradymia canescans) also have been used for cover. Sagebrush habitats vary considerably across the range of sage-grouse, and the specific habitat components used by the species vary with the season, location, and the type and condition of the plant communities (68 FR 6500; Connelly et al. 2004).

\subsubsection{Breeding and Brood-Rearing Habitat}

Sage-grouse breeding habitats are defined as those where lekking, nesting, and early brood-rearing occur. Leks are natural or man-made openings in the sagebrush canopy where sage-grouse traditionally gather to perform courtship display. Leks are situated on gentle terrain (Schroeder et al. 1999; Connelly et al. 2004), range in size from less than 0.4 ha ( 1 ac) to more than 40 ha (100 ac) (68 FR 6500), and often occur in the same location each year (Connelly et al. 2004).

Sage-grouse nest in sagebrush with a native grass and forb understory (Connelly et al. 2004; Crawford et al. 2004). Most nests are located under sagebrush plants (Schroeder et al. 1999; Connelly et al. 2004), although other shrub or bunchgrass species are sometimes used (Schroeder et al. 1999; Connelly et al. 2004; Christiansen 2008). Early brood rearing may be the most limiting life stage for sage-grouse populations (Lyon 2000). Forb-rich habitats in proximity to sagebrush cover-which provide food, particularly forbs and insects, for the chicks - function as early brood-rearing habitat (Lyon 2000; Connelly et al. 2004; Schroeder et al. 1999; Kaiser 2006). Late brood-rearing habitats are those used by sage-grouse following drying of herbaceous vegetation in sagebrush uplands in summer. Sagegrouse often use sagebrush habitats and other adjacent habitats where forbs stay green throughout the summer, including riparian wet meadows and fields of alfalfa (Medicago spp.) that also provide an abundance of food (Schroeder et al. 1999; Connelly et al. 2004; Kaiser 2006). Sage-grouse may move up in elevation or select more moist areas during summer.

\subsubsection{Autumn and Winter Habitat}

Autumn is when the diet changes to predominantly sagebrush. During early autumn, grouse use sagebrush as well as adjacent habitats, including upland meadows, riparian areas, greasewood (Sarcobatus spp.) bottoms, alfalfa fields, and irrigated native hay pastures. As vegetation in these other habitats dries or is killed by frost, sage-grouse begin to congregate in predominantly sagebrush habitats (Connelly et al. 2004). Sage-grouse use sagebrush habitat for shelter and food during winter, and habitat selection during winter is influenced by several factors including topography and amount of sagebrush cover above the snow level (Schroeder et al. 1999; Connelly et al. 2004). 


\subsection{Movements}

Sage-grouse display considerable fidelity to their breeding and summering and wintering areas. Lek fidelity has been well documented in the species (Schroeder et al. 1999; Connelly et al. 2004; Holloran 2005; Kaiser 2006). Male sage-grouse may travel up to $2.1 \mathrm{~km}$ (1.3 mi) daily to the lek from feeding and resting areas (Connelly et al. 2004). During the breeding season, females typically travel less than $5 \mathrm{~km}$ (3 mi) to nest (Schroeder et al. 1999; Connelly et al. 2004; Holloran 2005; Kaiser 2006) but may travel up to $35 \mathrm{~km}$ (22 mi) after mating (68 FR 6500).

Although some sage-grouse are resident and do not travel more than $10 \mathrm{~km}$ (6 mi) annually (Connelly et al. 2000), local migration between seasonal habitats has been noted in many populations. Sage-grouse may move between seasonal habitats two and even three times during a year (Schroeder et al. 1999; Connelly et al. 2004). Autumn migration peaks in mid-October through late November, spring migration is mid-February through mid-March, and summer migration is late May through early August (Schroeder et al. 1999). Although these seasonal movements may be as far as $161 \mathrm{~km}$ (100 mi) in spring or autumn (Connelly et al. 2004; Schroeder et al. 1999), average total annual movements of migratory populations are generally less than 34 km (21 mi) (68 FR 6500; Schroeder et al. 1999). These movements result in some migratory sage-grouse occupying annual ranges exceeding $2,700 \mathrm{~km}^{2}\left(1678 \mathrm{mi}^{2}\right.$; Schroeder et al. 1999; Connelly et al. 2004, 2007). Populations are not always either resident or migratory but may be mixed (Manville 2004).

\subsection{Demographics}

As previously defined, leks are places where sage-grouse gather to breed. Leks are variable in size and can host a few to hundreds of males (68 FR 6500; Schroeder et al. 1999; Connelly et al. 2004). Historical leks are often used for many years, are typically larger than, and often surrounded by, smaller satellite leks, which may be less stable in size and location within the course of 1 year and between 2 or more years (68 FR 6500). Average distance between neighboring leks ranges between 1.4 and $5.1 \mathrm{~km}$ (about 1-3 mi) (Schroeder et al. 1999).

Males establish territories on leks and use these territories throughout the breeding season (up to 3 months between late February and early June). Male sage-grouse do not exhibit territorial behavior during any other time of year (Connelly et al. 2004). While adult males demonstrate high lek fidelity (return to the same lek year after year), sub-adult males drift from one lek area to another (Lyon 2000).

Nests are relatively simple and consist of scrapes on the ground. The peak of egg-laying and incubation ranges from late March through mid-June. Although hens rear only one brood per season (Schroeder et al. 1999), if a hen loses a clutch of eggs she may re-nest into early July (Schroeder et al. 1999; Connelly et al. 2004). Clutch size ranges from about six to nine eggs (Schroeder et al. 1999; Connelly et al. 2004, 2007; Kaiser 2006; Christiansen 2008). Incubation typically lasts 3-4 weeks, and the chicks leave the nest soon after hatching (Schroeder et al. 1999; Connelly et al. 2004). They are capable of weak flight by 10 days of age and strong flight by 5 weeks of age (Connelly et al. 2004). Nest success (i.e., proportion of all nests that hatch one egg or more in a season) varies from about $15 \%$ to 86\%, with an average of around 50\% (Schroeder et al. 1999; Connelly et al. 2004, 2007). 


\subsection{Longevity}

Sage-grouse typically live between 1 and 4 years; however, sage-grouse up to 10 years of age have been recorded in the wild. The annual mortality rate for sage-grouse may be $50 \%$ to $55 \%$; it is due mainly to low juvenile survival that is partially offset by high adult survival (Crawford et al. 2004). Consequently, sage-grouse generally exhibit relatively low fecundity compared to other gallinaceous birds, such as pheasants, turkeys, grouse, partridges, quails, and chickens (Connelly et al. 2004; Christiansen 2008). Females generally have a higher survival rate than males, which accounts for a female-biased sex ratio (1:1 to 1:6 [Schroeder et al. 1999]) in adult birds (68 FR 6500).

The primary cause of mortality in sage-grouse is predation on eggs and birds (Schroeder et al. 1999; Connelly et al. 2004). Other causes of mortality include vehicles, electric power lines, fences, livestock, farm machinery, pesticides, drought, and fire (Connelly and Braun 1997; Schroeder et al. 1999). There has been little range-wide effort to examine the seasonal patterns of mortality. However, most research suggests that over-winter mortality is low (Connelly et al. 2004).

Most evidence indicates that populations do not fluctuate in regular cycles (Schroeder et al. 1999; Connelly et al. 2004); there is no boom-and-bust phenomenon similar to that of snowshoe hares (Lepus americanus) and ruffed grouse (Bonasa umbellus) (Connelly et al. 2007). Nest success is usually cited as the most significant factor influencing population dynamics in sage-grouse; nesting likelihood, re-nesting likelihood, juvenile survival, and adult survival are also important factors. Nest success appears to be influenced by extrinsic factors such as weather, habitat alteration, and predators (Moynahan et al. 2007). Similar factors may also influence juvenile survival and thus their recruitment in the population (Schroeder et al. 1999).

\subsection{Distribution, Abundance, and Population Trends}

Prior to European expansion into western North America, sage-grouse were believed to occur throughout the western United States (Figure 1) and occupied more than 1 million km² (Schroeder et al. 2004). The distribution of sage-grouse has contracted in a number of areas. They are now extirpated from Arizona, British Columbia, Nebraska, New Mexico, and Oklahoma; it is estimated they occupy about 56\% of the original range (Connelly and Braun 1997; Connelly et al. 2004). Currently, sage-grouse occur in California, Colorado, Idaho, Montana, Nevada, North Dakota, Oregon, South Dakota, Utah, Washington, and Wyoming (Connelly and Braun 1997; Schroeder et al. 1999).

Estimating population levels of sage-grouse can be difficult and somewhat problematic. States began monitoring sage-grouse populations in the 1940s and 1950s, but methods varied (Connelly et al. 2004). All states and provinces monitor sage-grouse populations annually using lek counts and sometimes additional survey methods. Variation in survey protocol makes it difficult to understand recent spatial and temporal population trends (Connelly et al. 2004). However, when count methods are standardized by examining changes at small spatial scales, almost all sage-grouse populations have declined significantly since the mid-1960s, and lek size has decreased. Only two of ten states and provinces appear to have stable or slightly increasing sage-grouse populations (Connelly et al. 2004). Sage-grouse are currently abundant enough to allow legal hunting in 10 states, although seasons have been more restrictive since the 1990s (Connelly et al. 2003, 2004). 


\subsection{Conservation Status}

In 2001, the USFWS found that listing the sage-grouse distinct population segment (DPS) in Washington State as threatened or endangered was warranted but precluded by other higher-priority listing actions (66 FR 22984). The sage-grouse DPS in Washington State still is considered to be a candidate for listing. In 2002 and 2003, the USFWS received three petitions to list sage-grouse as a threatened or endangered species range-wide. In 2005, the USFWS found that listing the sage-grouse was not warranted (70 FR 2244). In 2008 the USFWS initiated a second status review to consider information that has become available since its 2005 finding and to determine anew whether listing the sage-grouse as a threatened or endangered species range-wide is warranted (73 FR 10218). Although interim status results did not appear to favor listing (Hall 2008), the finding on this petition is pending. 


\subsection{Impacts Related to Energy Development}

Naugle et al. (in press) provided the most recent review of the response of sage-grouse to energy resource development (oil and gas) by synthesizing the most rigorous scientific literature on the subject from 1980 through 2008. All the literature reviewed by Naugle and colleagues reported negative impacts of energy development on sage-grouse; none reported any positive effects of development on either populations or habitat. Although it is certain that energy development causes declines in sage-grouse populations, the exact mechanisms responsible for declines are partially unknown (Naugle et al., in press).

Both direct and indirect impacts to sage-grouse may result from energy resource development. Direct impacts can result when animals avoid human infrastructure or when development directly affects survival or reproduction. Sage-grouse habitat declines when birds behaviorally avoid infrastructure in one or more seasons. Populations decline when cumulative impacts of development negatively affect reproduction and survival, or both. Avoidance that shrinks the distribution of sage-grouse may result in population declines if density-dependence, competition, or displacement into poor-quality habitats lowers survival or reproduction among displaced birds. Indirect impacts include habitat loss, fragmentation, or degradation; increased predation; or disease dynamics; and may be equally as deleterious as direct impacts (Naugle et al., in press).

Impacts from energy development accrue both locally and cumulatively at the landscape scale (Naugle et al., in press). Accumulated evidence across landscape-scale studies suggests that sage-grouse populations typically decline following oil and gas development (Holloran 2005; Walker et al. 2007; Doherty et al. 2008; Naugle et al., in press,). For example, development in excess of one well $\mathrm{pad} / 2.6 \mathrm{~km}^{2}\left(1 \mathrm{mi}^{2}\right)$ resulted in impacts to breeding populations; impacts at conventional well densities, eight pads/2.6 km² $\left(1 \mathrm{mi}^{2}\right)$, exceeded the species' threshold of tolerance (Naugle et al., in press).

Negative impacts to sage-grouse have been associated with three different types of fossil fuel development—shallow coal-bed natural gas (CBNG) (Walker et al. 2007; Doherty et al. 2008), deep gas (Lyon and Anderson 2003; Holloran 2005; Kaiser 2006), and oil extraction (Aldridge and Boyce 2007). Oil and gas infrastructure and associated human activity have been shown to adversely affect sage-grouse populations collectively and, in some instances, impacts have been attributed to certain anthropogenic features (e.g., roads, power lines).

Sage-grouse responses to general oil and gas development and to specific manmade features associated with those developments are described in the following paragraphs. The studies from which the information is drawn were conducted in the eastern portion of the species' range. The descriptions may apply also to sage-grouse responses to future wind energy resource development, to the extent that associated activities and infrastructure are similar to those of oil and gas resource development.

\subsection{Lek Abandonment}

Lek use is widely studied to monitor sage-grouse population size and distribution locally and at the landscape scale. The results of studies of lek use decline and lek abandonment attributed to oil and gas development are synthesized here. Factors affecting lek use and persistence are put forth with information on the effective distance of such factors and time period required to detect lek abandonment 
following oil and gas field development. It is likely that similar types of effects would be observed in relation to wind energy development.

In the Powder River Basin of northeastern Wyoming from 2001 to 2005, the number of males observed on leks inside CBNG fields that had been confirmed active in 1997 declined more rapidly than leks outside the CBNG fields. Lek count indices (counts of birds at leks that provide an indication of population size [Walsh et al. 2004]) inside gas fields declined by $82 \%$, whereas indices outside such development declined by $12 \%$. By 2005, leks in CBNG fields had $46 \%$ fewer males per active lek than leks outside the fields. Of leks active in 1997 or later, only 38\% of 26 leks in CBNG fields remained active by 2004-2005, compared to 84\% of 250 leks outside CBNG fields. Persistence of 110 leks was influenced positively by the proportion of sagebrush habitat. Lek persistence was influenced negatively by CBNG development and the proportion of power lines (considered as two separate factors) within 6.4 $\mathrm{km}$ (about $4 \mathrm{mi}$ ) of the lek, as well as the proportion of (heavily traveled all weather) roads within $3.2 \mathrm{~km}$ (about $2 \mathrm{mi}$ ) of the lek. Full development of the landscape within $3.2 \mathrm{~km}$ of leks reduced the average probability of lek persistence from $87 \%$ to $5 \%$. Leks disappeared on average within 3-4 years of CBNG development. It is nevertheless unclear whether declines in lek attendance within CBNG fields were caused by impacts to breeding birds at the lek, reduced survival or productivity of birds in the surrounding area, avoidance of developed areas, or some combination thereof (Walker et al. 2007).

Three studies were conducted in the Pinedale Anticline area of southwestern Wyoming-one during the initial stages of natural gas development (Lyon 2000) and two in more full stages of development (Holloran 2005; Kaiser 2006). These studies describe reductions in lek fidelity of male and female sagegrouse in response to natural gas development.

Holloran (2005) found that in areas subjected to full-field natural gas development, populations of breeding males on leks declined by an average of 51\% compared to only a 3\% decline at undisturbed leks. Males at three leks surrounded by natural gas development declined by $89 \%$, and two of the three leks were abandoned within 3-4 years of initiation of gas drilling. Active drilling within $5 \mathrm{~km}(3.1 \mathrm{mi})$ of a sage-grouse lek reduced the number of breeding males by displacing adult males and reducing recruitment of juvenile males. Increases in road traffic and well density also reduced the number of breeding males at leks.

Kaiser (2006) reported that yearling males tended to avoid leks (less recruitment) highly immersed into developing gas fields and, as distance from drilling rigs decreased, there was less recruitment. Hens continued to breed and initiated nests despite natural gas development; however, yearling hens tended to avoid visiting leks as proximity to a producing well increased. Both yearling males and females ( $9 \%$ and $11 \%$, respectively) showed low fidelity to natal leks. Forty-three percent of yearling males and $14 \%$ of yearling females established a lek within $5 \mathrm{~km}$ of the nest location from which they hatched, indicating some level of natal area fidelity but less philopatry than sage-grouse in other studies, in which 53-100\% fidelity was observed.

Lyon (2000) found a small number of males returning to breed on the same lek during 2 years despite disturbance from natural gas development. However, at the time of the Lyon study, gas development in the area was in its initial stages (in contrast to being more developed during the later studies [Holloran 2005; Kaiser 2006]), and impacts on lek fidelity could take longer to detect (Holloran 2005; Walker et al. 2007). To maintain a stable number of males using a lek, yearling recruitment must equal adult mortality. Assuming 50\% mortality (Connelly et al. 2004) and no yearling recruitment, the number of males 
attending a lek would decline by 50\% per year, and the lek would become inactive within 4-6 years, the approximate amount of time lag documented by Walker et al. (2007) and Holloran (2005). Thus, the Lyon (2000) study may have begun too early during gas development and not lasted long enough to detect differences in lek attendance.

Male and female sage-grouse may abandon leks if repeatedly disturbed by raptors perching on nearby power lines (Ellis 1984; Braun et al. 2002; Connelly et al. 2004), by vehicle traffic on nearby roads (Lyon and Anderson 2003), or by noise and human activity associated with energy development during the breeding season (Braun et al. 2002; Connelly et al. 2004; Holloran 2005; Kaiser 2006). Braun et al. (2002) reported that sage-grouse were particularly susceptible to the placement of overhead power lines at within $0.8 \mathrm{~km}(0.5 \mathrm{mi})$ of nesting grounds. Significant impacts to sage-grouse have been documented from overhead power transmission and communication distribution lines out to $6 \mathrm{~km}$ (3.7 mi) (Manville 2004). Collisions with power lines and vehicles and increased predation by raptors may increase mortality of birds at leks (Connelly et al. 2000). Further, sage-grouse mortality associated with roads and power lines occurs year-round (Walker et al. 2007). Thus, roads and power lines may also alter the productivity or survival of sage-grouse outside the reproductive season, thereby indirectly reducing the number of birds that use leks, increasing lek abandonment (Naugle et al., in press).

\subsection{Nesting Area Fidelity and Reproductive Success}

Other attributes of species reproduction are studied to monitor sage-grouse populations locally and at the landscape scale. This subsection synthesizes the results of studies of declines in reproductive metrics, such as nest initiation, nest area fidelity, and adult and chick survival, which are attributed to oil and gas development. Factors affecting these declines are put forth with information on the effective distance of such factors. It is likely that similar types of effects would be observed in relation to wind energy development.

In the Pinedale Anticline area, Lyon and Anderson (2003) found that the nest initiation rate for females from leks disturbed by natural gas development was $24 \%$ lower than for females from undisturbed leks, and that hens from disturbed leks traveled twice as far to nest sites (Lyon 2000). In habitat fragmented by natural gas development, only $26 \%$ of hens captured on disturbed leks nested within $3 \mathrm{~km}(1.8 \mathrm{mi})$ of the lek of capture, whereas 91\% of hens from undisturbed areas nested within 3 $\mathrm{km}$ of the lek of capture. Average distance between nests in consecutive years was $0.6 \mathrm{~km}$ (0.37 mi), indicating hens initially shifted nest locations due to disturbance but afterward showed fidelity to newfound nest locations (Lyon and Anderson 2003).

Holloran (2005) found that females strongly avoided nesting in areas of high well density, and there was a $21 \%$ decline in the population of nesting females compared to undisturbed females over the 5 years of the study. Females nesting in developed areas had a significantly lower survival rate than female grouse in undeveloped areas. Although nest success rates were higher in developed areas, this increase was not sufficient to overcome the reduced female survival rates, resulting in an overall $21 \%$ decline in sage-grouse population growth in developed gas fields compared to undeveloped areas. The distance between selected nesting sites and gas field infrastructure shifted between 2000-2003 and 2004, with females selecting nesting habitat farther from active drilling and producing wells in 2004. Population reductions likely resulted from a combination of dispersal away from gas fields and increased mortality rates for birds affected by development. A lag period occurs between the time when female sage-grouse 
are affected by development and when survival probabilities are influenced, suggesting negative fitness consequences for females subjected to natural gas development during the breeding and nesting periods.

In the Manyberries oil field in southeastern Alberta, sage-grouse selected heterogeneous patches of moderate sagebrush cover and avoided anthropogenic edge habitat for nesting (Aldridge and Boyce 2007). Nests were more successful in heterogeneous than anthropogenic edge habitats, but nest success was independent of anthropogenic features. Similarly, broods selected heterogeneous high-productivity habitats with sagebrush (at $>1 \mathrm{~km}^{2}$ ) while avoiding human developments, cultivated cropland, and high densities of oil wells. Chick mortalities tended to occur in proximity to oil and gas developments and along riparian habitats. Limited source habitats appear to be the main reason for poor nest success (39\%) and low chick survival (12\%) (Aldridge and Boyce 2007). Risk of chick mortality was 1.5 times higher for each additional well site visible within $1 \mathrm{~km}(0.6 \mathrm{mi})$ of brood-rearing habitat (Aldridge 2005; Aldridge and Boyce 2007).

\subsection{Winter Habitat Use}

Avoidance of winter habitat is also known to occur in relation to oil and gas development and may affect the viability of sage-grouse populations. In the Powder River Basin, sage-grouse avoided CBNG

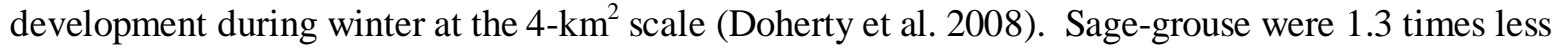
likely to use otherwise suitable winter habitats that had been developed for CBNG at a density of 12

wells $/ 4 \mathrm{~km}^{2}$. Impacts were indiscernible at densities of 1-12 wells within $32.2 \mathrm{~km}^{2}$ of a lek ( 1 well/640 ac) (Doherty et al. 2008). Impacts to winter habitat may have a disproportionate effect on regional sagegrouse population size and persistence if the species uses a small percentage of available sagebrush habitat in an area (Doherty et al. 2008). 


\subsection{Knowledge Gaps and Future Research}

Both wind farms and oil and gas fields consist of large aggregations of infrastructure and activities that share some common features, such as transmission lines and roads, and differ in others, such as wind turbines. Impacts to sage-grouse from wind energy development would likely be similar to those resulting from fossil fuel development described in Section 4. However, the extent of potential impact is unknown because no such research has been completed to quantify wind energy effects on sage-grouse. It is not known to what extent wind farms would mimic gas and oil fields with respect to effects that occur beyond the footprint of ground disturbance, or how the presence of tall towers with turbines would affect sage-grouse. How sage-grouse populations respond to wind energy development could be related to the locations and densities of individual towers, the size and layout of individual wind farms, the density of wind farms across the landscape, and the amount and distribution of support infrastructure (roads, transmission lines). Very little information is currently available to address these information needs.

\subsection{Research Needs and Priorities}

Wind energy development is expected to disturb sagebrush habitat where sage-grouse occur. Cooccurrence of wind developments with other forms of development (e.g., oil and gas, agriculture) may cumulatively or synergistically increase effects on sage-grouse both locally and regionally. Thus, there appears to be an imminent need for research on the effects of wind energy development on sage-grouse.

Information on the local and landscape-level impacts of wind energy development on sage-grouse is needed so that effective mitigation measures and broad conservation strategies could then be developed as necessary. Mitigation measures could include siting, construction, and operation constraints and guidelines (e.g., setback distances and densities for turbines and infrastructure) for wind energy facilities.

Experimentation is the most reliable means of understanding responses of sage-grouse to wind energy development. Prior to construction of the facility, research should be conducted in a manner to adequately characterize variability in important population parameters (e.g., population levels, habitat use, lek fidelity, nest area fidelity, reproductive success, and recruitment) of sage-grouse that could be affected. Knowledge could be advanced using before-after control-impact (BACI) study designs (72 FR 54233; Aldridge et al. 2004) with radio-marked birds (Walker et al. 2007) and could be used within an adaptive management strategy by the authorizing and permitting agencies (e.g., BLM, U.S. Forest Service [USFS], state agencies) and the wind energy industry (Aldridge et al. 2004). Unaffected sage-grouse populations would serve as a control. Study areas should be large enough or be configured such that they comprise both affected and unaffected populations. One purpose of preconstruction research could be to site turbines (location and configuration) to minimize potential impacts to the species and for comparison with construction and post-construction research data. To minimize confounding variables, study areas initially should not have other energy development pressure on the landscape (oil and gas) when possible. Post-construction research should be conducted to adequately characterize sage-grouse responses to the infrastructure and human activities that are part of facility operation. Lek counts are widely used to monitor sage-grouse populations and, at present, are the only data suitable for examining trends in population size and distribution at the landscape scale. Due to the observed lag time of 3-4 years for observed changes in lek attendance following oil and gas development, surveys to detect impacts related to wind energy should account for this phenomenon (Walker et al. 2007). If a different metric were used 
to characterize changes in population size or habitat use, the duration of post-construction monitoring should reflect the timeframe needed to detect associated effects.

Understanding how wind energy development affects sage-grouse populations requires control of other landscape features that affect population size and persistence, including the extent of suitable habitat. For example, variation in the amount of sagebrush habitat available for foraging and nesting is likely to influence the size of breeding populations and persistence of leks (Schroeder et al. 1999). Thus, it would be useful to quantify and separate the effects of habitat loss caused by a facility from the effects of interest (e.g., population health and persistence metrics such as those described in Section 4) that extend well beyond the limits of ground disturbance (Walker et al. 2007). Effects of interest should be analyzed along a distance and density gradients where possible.

As with any field research, unforeseen developments may reduce the likelihood that research plans are fully realized. A number of collaborative efforts between the energy industry, research community, and land management agencies exist to deal with energy development and resource conservation issues. The Grassland and Shrub Steppe Species Collaborative or the conceptualized sage-grouse wind energy collaborative could be utilized to design research protocols and coordinate research efforts among different wind energy projects. This collaboration could account for changes in experimental design, thereby standardizing effort, increasing effectiveness, and potentially reducing cost.

\subsection{Application of Research to Federal and State Land-Use Authorizations}

The results of future research on the effects of wind energy development on sage-grouse may be used in decision making for subsequent wind energy projects and concurrent conservation of the species. The results of sage-grouse research could inform right-of-way granting for federal and state land-use authorizations to access, test, site, permit, and construct and operate (including transmission lines) a new wind energy facility. The BLM and USFS each has its own land-use authorization process and associated National Environmental Policy Act (NEPA) analyses related to wind energy development. These are described in the Appendix to this report, with emphasis on the portions relevant to wind energy development that could be influenced by the findings of wind energy research on sage-grouse. General descriptions of the USFWS guidelines for wind energy developments and state conservation plans for the sage-grouse also are included in the Appendix. These guidelines and plans could be updated and used to inform decisions involving federal and state land-use authorizations and NEPA analyses.

\subsection{Application of Research to Mapping Sage-Grouse Habitat Attributes}

The extent of current sage-grouse habitat is well known due to many range-wide mapping efforts (GAP, SAGEMAP, LANDFIRE) in the past 10 to 15 years. Although the habitat extent is fairly well known across the sagebrush biome, specific habitat characteristics (sagebrush canopy cover, understory grass, and forb components) that are important to sage-grouse population viability are difficult to quantify and map at the landscape scale. The development of techniques to monitor these variables across the landscape is in the early stages but shows promise toward filling knowledge gaps. Work by the U.S. Geological Survey in Wyoming has shown that with high-resolution satellite data and extensive field 
measurements, critical sage-grouse habitat attributes can be mapped with a high degree of accuracy (Homer et al. 2008). Studies done for the BLM and USFWS have shown success using freely available aerial photographic data to create shrub canopy cover maps. This technique, using very sparse field data with National Agricultural Imagery Program digital images, is very low-cost but characterizes only canopy cover and not the other habitat variables (Tagestad and Downs 2007). Acquiring data to map these habitat characteristics and monitor habitat changes across the range of sage-grouse may aid in the siting and development of energy resource facilities. 


\subsection{Literature Cited}

16 U.S.C. §§ 1531-1544, Endangered Species Act of 1973.

16 U.S.C. $\S \S 1600-1614$, National Forest Management Act of 1976.

42 U.S.C. §4331 et seq, National Environmental Policy Act of 1969.

66 FR 22984. 2001. Endangered and Threatened Wildlife and Plants; 12-month Finding for a Petition to List the Washington Population of Western Sage Grouse (Centrocercus urophasianus phaios). Federal Register. May 7, 2001.

68 FR 6500. 2003. Endangered and Threatened Wildlife and Plants; 90-day Finding on a Petition to List the Western Sage Grouse. Federal Register. February 7, 2003.

70 FR 2244. 2005. Endangered and Threatened Wildlife and Plants; 12-month Finding for Petitions to List the Greater Sage-Grouse (Centrocercus urophasianus) as Threatened or Endangered; Proposed Rule. Federal Register. January 12, 2005.

72 FR 54233. 2007. Wind Energy, Proposed Forest Service Directives. Federal Register.

September 24, 2007.

73 FR 10218. Endangered and Threatened Wildlife and Plants; Initiation of Status Review for the Greater Sage-Grouse (Centrocercus urophasianus) as Threatened or Endangered. Federal Register. February 6, 2008.

Aldridge CL. 2005. Identifying Habitats for Persistence of Greater Sage-Grouse (Centrocercus urophasianus) in Alberta, Canada. Doctoral dissertation, University of Alberta, Edmonton, Alberta, Canada.

Aldridge CL and MS Boyce. 2007. Linking occurrence and fitness to persistence; habitat-based approach for endangered greater sage-grouse. Ecological Applications 17(2):508-526.

Aldridge CL, MS Boyce, and RK Baydack. 2004. Adaptive management of prairie grouse: how do we get there? Wildlife Society Bulletin 32(1):92-03.

Aldridge CL, SE Nielsen, HL Beyer, MS Boyce, JW Connelly, ST Knick, and MA Schroeder. 2008. Range-wide patterns of greater sage-grouse persistence. Diversity and Distributions 14(6):983-994.

Braun CE, OO Oedekoven, and CL Aldridge. 2002. Oil and gas development in western North America: effects of sagebrush steppe avifauna with particular emphasis on sage grouse. Transactions of the North American Wildlife and Natural Resources Conference 67:337-349.

Christiansen T. 2008. Hunting and Sage-Grouse: A Technical Review of Harvest Management on a Species of Concern in Wyoming. Wyoming Game and Fish Department, Cheyenne. Available at http://gf.state.wy.us/wildlife/wildlife_management/sageGrouse/index.asp (May 2009). 
Connelly JW and CE Braun. 1997. Long-term changes in sage grouse Centrocercus urophasianus populations in western North America. Wildlife Biology 3(3/4):229-234.

Connelly JW, MA Schroeder, AR Sands, and CE Braun. 2000. Guidelines to manage sage grouse populations and their habitats. Wildlife Society Bulletin 28(4):967-985.

Connelly JW, KP Reese, EO Garton, and ML Commons-Kemner. 2003. Response of greater sagegrouse Centrocercus urophasianus populations to different levels of exploitation in Idaho, USA. Wildlife Biology 9(4):335-340.

Connelly JW, ST Knick, MA Schroeder, and SJ Stiver. 2004. Conservation Assessment of Greater Sagegrouse and Sagebrush Habitats. Western Association of Fish and Wildlife Agencies, Cheyenne, Wyoming. Available at http://www.sagebrushsea.org/WAFWA_page.htm (May 2009).

Connelly JW, CE Braun, MA Schroeder, and CA Hagen. 2007. Setting the record straight: a response to "Sage-Grouse at the Crossroads.” Rangelands 29(6):35-39.

Crawford JA, RA Olson, NE West, JC Mosley, MA Schroeder, TD Whitson, RF Miller, MA Gregg, and CS Boyd. 2004. Ecology and management of sage-grouse and sage-grouse habitat. Journal of Range Management 57:2-19.

Delach A. 2006. Invasive species in the northwestern United States: threats to wildlife and defenders of wildlife’s recommendation for prevention policies. Northwestern Naturalist 87:43-55.

DOE (U.S. Department of Energy). 2008. 20\% Wind Energy by 2030: Increasing Wind Energy's Contribution to U.S. Electricity Supply. DOE/GO-102008-2567, Office of Energy Efficiency and Renewable Energy, U.S. Department of Energy, Washington, D.C. Available at http://www1.eere.energy.gov/windandhydro/wind_2030.html (May 2009).

Doherty KE, DE Naugle, BL Walker, and JM Graham. 2008. Greater sage-grouse winter habitat selection and energy development. Journal of Wildlife Management 72(1):187-195.

DOI (U.S. Department of the Interior). 2005a. Final Programmatic Environmental Impact Statement on Wind Energy Development on BLM-Administered Lands in the Western United States. FES 05-11, U.S. Department of the Interior, Bureau of Land Management, Washington, D.C.

Ellis KL. 1984. Behavior of lekking sage grouse in response to a perched golden eagle. Western Birds 15:37-38.

Hall HD. 2008. Memorandum to Assistant Secretary for Fish and Wildlife and Parks (U.S. Department of the Interior) from H. Dale Hall (Director, U.S. Fish and Wildlife Service), Greater Sage Grouse Interim Status Update Results, December 18, 2008 (FWS/D/039478). Available at www.fws.gov/mountainprairie/species/birds/sagegrouse/Dir\%20memo\%20to\%20ASFWP_18Dec08.pdf (May 2009).

Holloran MJ. 2005b. Greater Sage-Grouse (Centrocercus urophasianus) Population Response to Natural Gas Field Development in Western Wyoming. Doctoral dissertation, Department of Zoology and Physiology, University of Wyoming, Laramie. 
Homer CG, CL Aldridge, DK Meyeer, MJ Coan, and ZH Bowen. 2008. Multiscale Sagebrush Rangeland Habitat Modeling in Southwest Wyoming. Open-File Report 2008-1027, U.S. Geological Survey, Denver Federal Center, Denver, Colorado. Available at http://pubs.usgs.gov/of/2008/1027/ (May 2009).

Kaiser RC. 2006. Recruitment by Greater Sage-Grouse in Association with Natural Gas Development in Western Wyoming. Masters thesis, Department of Zoology and Physiology, University of Wyoming, Laramie.

Lyon AG. 2000. The Potential Effects of Natural Gas Development on Sage-Grouse Near Pinedale, Wyoming. Masters thesis, Department of Zoology and Physiology, University of Wyoming, Laramie.

Lyon AG and SH Anderson. 2003. Potential gas development impacts on sage-grouse nest initiation and movement. Wildlife Society Bulletin 31:486-491.

Manville AM II. 2004. Prairie Grouse Leks and Wind Turbines: U.S. Fish and Wildlife Service Justification for a 5-Mile Buffer from Leks; Additional Grassland Songbird Recommendations. Briefing Paper, Division of Migratory Bird Management, U.S. Fish and Wildlife Service, Arlington, Virginia. Available at http://www.environment.ok.gov/documents/OKWindEnergy/

PrairieGrouseLeksWindTurbines.pdf (May 2009).

Moynahan BJ, MS Lindberg, JJ Rotella, and JW Thomas. 2007. Factors affecting nest survival of greater sage-grouse in Northcentral Montana. Journal of Wildlife Management 71(6):1773-1783.

Naugle DE, KE Doherty, BL Walker, MJ Holloran, and HE Copeland. In press. Energy development and greater-grouse. Studies in Avian Biology.

Schroeder MA, JR Young, and CE Braun. 1999. Sage Grouse (Centrocercus urophasianus). In The Birds of North America, No. 425, A Poole and F Gill (eds). The Birds of North America, Inc., Philadelphia, Pennsylvania.

Schroeder MA, CL Aldridge, AD Apa, JR Bohne, CE Braun, SD Bunnell, JW Connelly, PA Deibert, SC Gardner, MA Hilliard, GD Kobriger, SM McAdam, CW McCarthy, JJ McCarthy, DL Mitchell, EV Rickerson, and SJ Stiver. 2004. Distribution of sage-grouse in North America. The Condor 106:363-376.

Tagestad JD and JL Downs. 2007. Landscape Measures of Shrubland Condition in the Bureau of Land Management Owyhee Pilot Project: Shrub Canopy Mapping, Vegetation Classification, and Detection of Anomalous Land Areas. PNNL-17209, Pacific Northwest National Laboratory, Richland, Washington.

Walker BL, DE Naugle, and KE Doherty. 2007. Greater sage-grouse population response to energy development and habitat loss. Journal of Wildlife Management 71(8):2644-2654.

Walsh DP, GC White, TE Remington, and DC Bowden. 2004. Evaluation of the lek count index for greater sage-grouse. Wildlife Society Bulletin 32(1):56-58. 


\section{Appendix A}

Application of Research to Federal and State Land-Use Authorizations 


\section{Appendix A}

\section{Application of Research to Federal and State Land-Use Authorizations}

\section{A.1 Bureau of Land Management}

The Bureau of Land Management (BLM) administers public lands under the Federal Land Policy and Management Act of 1976 (FLPMA) and 43 CFR subpart 2802. The BLM's chief administrative devices are the land-use plan [43 USC §1712(a)] and resource management plan [43 CFR Parts 1601.0-5(n)], both of which observe principles of multiple use and sustained yield [43 USC §1712(c)(1)]. Under the FLPMA, BLM grants land-use authorizations and conducts NEPA analyses for siting projects on public lands, both of which play a role in balancing wind energy development and sage-grouse conservation (BLM 2004).

\section{A.1.1 Land-Use Authorizations}

The BLM issued Instruction Memorandum (IM) No. 2009-043 Regarding Wind Energy Development Policy on December 9, 2008 (BLM 2008a). The IM provides guidance on processing right-of-way (ROW) applications to grant authorized use of land for three phases of wind energy development on public lands administered by the BLM:

1. site-specific grant - minimum amount of land for permitted site testing equipment such as individual meteorological towers and instrumentation facilities

2. testing and monitoring grant - reasonable amount of land for testing and monitoring for a full-scale wind energy project in the future

3. project development grant - reasonable amount of land for construction of turbines, access roads, distribution lines, and associated facilities.

The IM (BLM 2008a) establishes mechanisms to protect and enhance natural resources and to identify the issues and concerns that need to be addressed by project-specific plans. It also requires that mitigation measures to protect these resources be incorporated into each project's plan of development (POD). The IM clarifies BLM wind energy development policies and best management practices (BMP) (BLM 2008b). Wildlife BMPs are considered most extensively at a project's POD phase. These BMPs include designing the project and developing a habitat restoration plan to avoid, minimize, or mitigate impacts to federal and state protected species, including priority wildlife and special status animal species (BLM 2008b). Wildlife BMPs at the construction phase concern timing activities to avoid impacts to wildlife (BLM 2008b). The IM also takes into consideration but does not mandate compliance with the U.S. Fish and Wildlife Service (FWS) "Interim Guidelines to Avoid and Minimize Wildlife Impacts from Wind Turbines” of July 2003 (see below) (BLM 2008a; USFWS 2003). Any new wind energy project that would create, revise, or amend a BLM land use plan must comply with the IM. The results of research on the effects of wind energy on sage-grouse could be used to inform the ROW granting process for specific wind development projects and associated BMPs that affect the design of the 
project. Site-specific opportunities for conservation would be broader prior to granting land for actual facility construction.

\section{A.1.2 NEPA Analyses}

The BLM and U.S. Department of Energy (DOE) began assessing the potential for renewable energy on public lands in the western United States in 2003 (DOI and DOE 2003). In 2005, the BLM issued a programmatic environmental impact statement (PEIS) and associated Record of Decision (ROD) for wind energy development in 11 western states (DOI 2005a, b). The PEIS proposed action was to implement a wind energy development program under a maximum potential development scenario. The PEIS amended 52 BLM land-use plans and provides the foundation for environmental analysis of future wind proposals on BLM land.

In 2008, the DOE and BLM issued a PEIS (DOE and DOI 2008) designating about 9,600 km (6,000 mi) of energy corridors in 11 western states under Section 368 of the Energy Policy Act of 2005. The BLM issued an associated ROD (BLM 2009) to amend 92 affected land-use plans. About $82 \%$ of the corridors would occur on BLM land, about $16 \%$ on U.S. Forest Service land, and about $2 \%$ on other lands. Energy corridors are a designation applied to federal lands where the construction, operation, or upgrade of one or more energy transport projects is preferred. Corridors may assist in minimizing impacts that would be caused by the proliferation of separate ROWs. Corridors are sited to the maximum extent possible to promote renewable energy development in the western United States (BLM 2009). No construction, upgrade, or operation may occur without an authorized ROW and appropriate NEPA review.

The NEPA analyses for specific wind development projects would tier off both the 2005 and 2008 PEISs. The results of research on the effects of wind energy on sage-grouse would be used to inform NEPA analyses and decision making for specific wind energy projects and sections of energy corridors and tie-in distribution lines used by such projects.

\section{A.1.3 Energy Development Restrictions for Sage-Grouse}

In Montana, mitigation for sage-grouse on BLM lands undergoing oil and gas development typically includes lease stipulations prohibiting surface infrastructure within $0.4 \mathrm{~km}(0.25 \mathrm{mi})$ of active leks, as well as restrictions on timing of drilling and construction within $3.2 \mathrm{~km}$ (about $2 \mathrm{mi}$ ) of documented leks during the March 15-June 15 breeding season and within crucial winter habitat December 1-March 31 (Walker et al. 2007).

The Pinedale Anticline ROD (BLM 2000) (Wyoming) outlined the following development stipulations for protection of greater sage-grouse leks:

Operators will avoid surface disturbance within $0.4 \mathrm{~km}(0.25 \mathrm{mi})$ of greater sage-grouse leks; permanent (life of the project), high-profile facilities (i.e., buildings and storage tanks) should not be constructed within $0.4 \mathrm{~km}(0.25 \mathrm{mi})$ of a lek.

From March 1 through May 15, surface use and activities are not allowed between 0000 hours (i.e., midnight) and 0900 hours within a $0.8-\mathrm{km}(0.5-\mathrm{mi})$ radius of active leks (i.e., leks occupied by mating birds). 
Operators will restrict construction and drilling activities from March 1 through May 15 within a 1.6$\mathrm{km}(1.0-\mathrm{mi})$ radius of active leks.

To protect nesting and brooding females, the Pinedale Anticline ROD (BLM 2000) stipulated that gas field related construction activities will be restricted from March 1 through July 31 in suitable nesting habitat within $3.2 \mathrm{~km}$ (2 mi) of active greater sage-grouse leks; a suitable habitat designation requires that an active nest be located during an onsite review of the proposed development area (Holloran 2005; Kaiser 2006; Lyon 2000).

The Holloran study (2005) results suggest that current development stipulations are inadequate to maintain greater sage-grouse breeding populations in natural gas fields. A minimal level of development within $3 \mathrm{~km}$ of a lek negatively influences breeding activity. Maintaining well densities of 1 well or fewer per 283 ha (approximately 1 well per section) within $3 \mathrm{~km}$ (1.8 mi) of a lek could reduce the negative consequences of gas field development. The distance from disturbance sources that produced substantial levels of noise (i.e., drilling rigs, compressor stations, heavy construction equipment) during the breeding season was conservatively estimated at $5 \mathrm{~km}$ (3.1 mi), especially if the source was located where sound propagation towards leks was intensified by environmental factors. Therefore, sound muffling devices or other techniques of sound reduction on noisy gas field structures within $5 \mathrm{~km}$ of a lek could reduce the negative consequences of these structures on breeding grouse. Declines in lek attendance were positively correlated with vehicle traffic levels, and vehicular activity during the daily strutting period on roads within $1.3 \mathrm{~km}$ of a lek intensified the negative influence of traffic. Reducing overall traffic volumes (i.e., offsite condensate collection facilities, carpooling) and isolating traffic disturbance (i.e., restricting travel to and from the gas field to one major artery) within gas fields could reduce road effects. Additionally, enforcement of daily travel timing restrictions could further dampen road effects (Holloran 2005).

The 0.4-km restriction has been shown to be inadequate to ensure lek persistence, and seasonal drilling restrictions do not address the long-term effects (e.g., avoidance, collisions, raptor predation) of constructed facilities on populations over much longer periods of time. Full development of the landscape within $3.2 \mathrm{~km}$ of leks reduced the average probability of lek persistence from $87 \%$ to $5 \%$ (Walker et al. 2007). The $0.4-\mathrm{km}$ restriction has been shown to be inadequate also because it forms an area $\left(0.5 \mathrm{~km}^{2}\right)$ that is eight times smaller than the scale at which individual sage-grouse select winter habitats $\left(4 \mathrm{~km}^{2}\right)$. Timing restrictions are also inadequate because they do not prevent infrastructure from displacing sage-grouse during winter, and allow human access to all areas throughout the life of the producing gas field (Doherty et al. 2008). The 0.4-km restriction appears insufficient, as it leaves $98 \%$ of the landscape within $3.2 \mathrm{~km}$ open to development (Naugle et al., in press). Such restrictions are apparently insufficient for oil and gas development and may or may not be suitable for wind energy development. Thus, this area would benefit from future research on the effects of wind energy development on sage-grouse.

\section{A.2 U.S. Forest Service}

The U.S. Forest Service (USFS) administers public lands under the National Forest Management Act or 1976 (NFMA). The USFS chief administrative device is the land and resource management plan [16 USC §1604(a)]. Proposals for wind energy facilities are processed under special use regulations and policies [43 U.S.C. §§ 1761-1771; 36 CFR part 251, subpart B; Forest Service Manual (FSM) 2726.02a 
and 2726.21; Forest Service Handbook (FSH) 2709.11], which are consistent with the land management plans and NEPA analysis.

The USFS proposed to amend its internal agency directives for special use permits and wildlife monitoring specific to wind energy development (72 FR 54233). The new directive would add a new Chapter 70, “Wind Energy Uses," to the Special Uses Handbook, FSH 2709.11, and a new Chapter 80, "Monitoring at Wind Energy Sites," to the Wildlife and Fisheries Program Management Handbook, FSH 2609.13. New Chapter 80 would provide specific guidance on wildlife monitoring at wind energy sites before, during, and after construction, including federally protected species and other species of management concern or high public interest. Information would be used to develop mitigation measures to reduce adverse effects to wildlife. The use of before-after control-impact (BACI) study designs would be recommended to elucidate impacts from the construction and operation of a wind energy facility. The purpose of pre-construction monitoring would be to site turbines (location and configuration) to reduce potential impacts to wildlife. The purpose of post-construction monitoring would be to alter the structure and operation of the facility to reduce actual impacts to wildlife (72 FR 54233). These Chapter 80 recommendations align with the research needs discussed in Section 5 of this document for sage-grouse, the results of which could be used to inform the siting, design, and post-construction modification of wind energy facilities on USFS lands.

\section{A.3 USFWS Interim Guidelines}

The U.S. Fish and Wildlife Service (USFWS) developed "Interim Guidelines to Avoid and Minimize Wildlife Impacts from Wind Turbines” in July 2003 (USFWS 2003; Manville 2004). Guidelines specific to sage-grouse or with relevance to the species include (USFWS 2003)

- configuring turbines to maintain areas of contiguous habitat (i.e., avoid fragmentation)

- placing turbines on lands already altered or cultivated and away from areas of intact and healthy native habitats

- avoiding placing turbines within $8 \mathrm{~km}$ (5 mi) of known leks

- placing electric power lines underground.

Connelly et al. (2000) recommended protecting suitable habitat out to $3.2 \mathrm{~km}$ (2 mi) from all occupied leks for nonmigratory sage-grouse populations occupying uniformly distributed habitat; suitable habitat out to $5 \mathrm{~km}$ (3.1 mi) from all occupied leks for non-migratory populations occupying nonuniformly distributed habitat; and breeding habitats within $18 \mathrm{~km}$ (11.2 mi) of active occupied leks for migratory populations, recognizing that nesting birds may move more than18 km) from leks to nest sites. The USFWS guideline to avoid placing turbines within $8 \mathrm{~km}(5 \mathrm{mi})$ of known leks is based on professional judgment and is therefore subject to revision (Manville 2004). The guidelines also recommend pre- and post-construction research and monitoring to identify and/or assess impacts to wildlife. The interim guidelines were based on current science and would be updated as new information became available (USFWS 2003). The results of research on the effects of wind energy on sagegrouse could be used to update these guidelines. 


\section{A.4 State Conservation Plans}

Wind energy development may require siting approval or certification from state energy authorities. Approval may be needed also from states to connect the project to the local electric grid system. Certain states have environmental policy acts equivalent to NEPA that are tied to the issuance of state-level environmental permits. Environmental analyses that support decisions to issue certifications, approvals, and permits may refer to state sage-grouse conservation plans in their decision documents. However, it should be noted that this apparently has not been the case with development of state minerals for natural gas, which have had few or no requirements to mitigate impacts on wildlife (Walker et al. 2007). State conservation plans to date typically have not considered wind energy development per se in the conservation of the species, although some plans may consider relevant project components separately, such as power lines. Thus, state sage-grouse conservation plans that could be used to support such decision making could also benefit from the results of research on the effects of wind energy on sagegrouse.

\section{A.5 Literature Cited}

36 CFR Part 251, Land Uses. U.S. Code of Federal Regulations.

43 CFR Part 1600, Planning, Programming, Budgeting. U.S. Code of Federal Regulations.

16 U.S.C. §§ 1600-1614, National Forest Management Act of 1976.

42 U.S.C. § 15801, Energy Policy Act of 2005.

43 U.S.C. § 1712, Land use plans.

43 U.S.C. § 1761, Grant, issue, or renewal of rights-of-way.

43 U.S.C. § 1763, Federal Land Policy and Management Act of 1976.

72 FR 54233. 2007. Wind Energy, Proposed Forest Service Directives. Federal Register. September 24, 2007.

FSH 2609.13. 1992. Wildlife and Fisheries Program Management Handbook. U.S. Department of Agriculture, Forest Service, Washington, D.C.

FSH 2709.11. 2003. Special Uses Handbook. U.S. Department of Agriculture, Forest Service, Washington, D.C.

FSM 2726. 1992. Energy Generation and Transmission. Subsection 2726 in Chapter 2720, Special Uses Administration, in Special Uses Management. FSM 2700, U.S. Department of Agriculture, Forest Service, Washington, D.C.

BLM (Bureau of Land Management). 2004. National Sage-Grouse Habitat Conservation Strategy. U.S. Department of the Interior, Bureau of Land Management, Washington, D.C. 
BLM (Bureau of Land Management). 2008a. Instruction Memorandum No. 2009-043 Regarding Rightof-Way Management for Wind Energy. Available at http://www.blm.gov/wo/st/en/info/ regulations/Instruction_Memos_and_Bulletins/national_instruction/2009/IM_2009-043.html (May 2009).

BLM (Bureau of Land Management). 2008b. Instruction Memorandum No. 2009-043 Regarding Rightof-Way Management for Wind Energy: Attachment 1 - BLM Wind Energy Program Policies and Best Management Practices. Available at http://www.blm.gov/wo/st/en/info/regulations/ Instruction_Memos_and_Bulletins/national_instruction/2009/IM_2009-043.html (May 2009).

BLM (Bureau of Land Management). 2009. Approved Resource Management Plan Record of Decision (ROD) for Designation of Energy Corridors on Bureau of Land Management-Administered Lands in 11 Western States. BLM/WO-GI-09-005-1800, U.S. Department of the Interior, Bureau of Land Management, Washington, D.C. Available at http://corridoreis.anl.gov/ (May 2009).

Connelly JW, MA Schroeder, AR Sands, and CE Braun. 2000. Guidelines to manage sage grouse populations and their habitats. Wildlife Society Bulletin 28(4):967-985.

DOE and DOI (U.S. Department of Energy and U.S. Department of the Interior, Bureau of Land Management). 2008. Programmatic Environmental Impact Statement, Designation of Energy Corridors on Federal Land in 11 Western States. DOE/EIS-0386, U.S. Department of Energy and U.S. Department of the Interior , Bureau of Land Management, Washington, D.C. Available at http://corridoreis.anl.gov//documents/fpeis/index.cfm (May 2009).

Doherty KE, DE Naugle, BL Walker, and JM Graham. 2008. Greater sage-grouse winter habitat selection and energy development. Journal of Wildlife Management 72(1):187-195.

DOI (U.S. Department of the Interior). 2005a. Final Programmatic Environmental Impact Statement on Wind Energy Development on BLM-Administered Lands in the Western United States. FES 05-11, U.S. Department of the Interior, Bureau of Land Management, Washington, D.C.

DOI (U.S. Department of the Interior). 2005b. Record of Decision: Implementation of a Wind Energy Development Program and Associated Land Use Plan Amendments. U.S. Department of the Interior, Bureau of Land Management. Washington D.C. Available at windeis.anl.gov/documents/docs/WindPEISROD.pdf (May 2009).

DOI and DOE (U.S. Department of the Interior and U.S. Department of Energy). 2003. Assessing the Potential for Renewable Energy on Public Lands. DOE/GO-102003-1704, U.S. Department of Energy, Office of Energy Efficiency and Renewable Energy, Washington, D.C. Available at www.nrel.gov/docs/fy03osti/33530.pdf (May 2009).

Holloran MJ. 2005b. Greater Sage-Grouse (Centrocercus urophasianus) Population Response to Natural Gas Field Development in Western Wyoming. Doctoral dissertation, Department of Zoology and Physiology, University of Wyoming, Laramie.

Kaiser RC. 2006. Recruitment by Greater Sage-Grouse in Association with Natural Gas Development in Western Wyoming. Masters thesis, Department of Zoology and Physiology, University of Wyoming, Laramie. 
Lyon AG. 2000. The Potential Effects of Natural Gas Development on Sage-Grouse Near Pinedale, Wyoming. Masters thesis, Department of Zoology and Physiology, University of Wyoming, Laramie.

Manville AM II. 2004. Prairie Grouse Leks and Wind Turbines: U.S. Fish and Wildlife Service Justification for a 5-Mile Buffer from Leks; Additional Grassland Songbird Recommendations. Briefing Paper, Division of Migratory Bird Management, U.S. Fish and Wildlife Service, Arlington, Virginia. Available at http://www.environment.ok.gov/documents/OKWindEnergy/ PrairieGrouseLeksWindTurbines.pdf (May 2009).

Naugle DE, KE Doherty, BL Walker, MJ Holloran, and HE Copeland. In press. Energy development and greater-grouse. Studies in Avian Biology.

USFWS (U.S. Fish and Wildlife Service). 2003. Interim Guidelines to Avoid and Minimize Wildlife Impacts from Wind Turbines. U.S. Department of the Interior, Fish and Wildlife Service, Washington, D.C. Available at http://www.fws.gov/habitatconservation/wind.pdf (May 2009).

Walker BL, DE Naugle, and KE Doherty. 2007. Greater sage-grouse population response to energy development and habitat loss. Journal of Wildlife Management 71(8):2644-2654. 


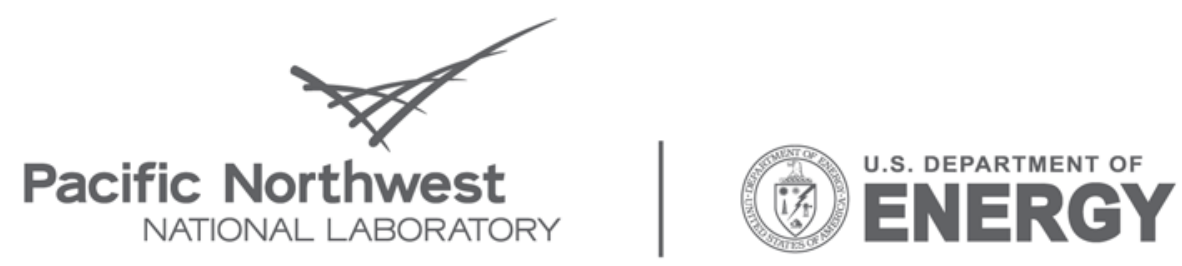

Proudly Operated by Battelle Since 1965

902 Battelle Boulevard

P.O. Box 999

Richland, WA 99352

1-888-375-PNNL (7665)

www.pnl.gov 